\title{
The lesson to be learned from Broccoli and turmeric
}

\author{
Rajasri Bhattacharyya, Vandana Singh and Dibyajyoti Banerjee* \\ Department of Experimental Medicine \& Biotechnology, Post Graduate Institute of Medical Education \& Research, Sector 12, Chandigarh, India
}

Broccoli, a salad vegetable, and turmeric, herbs are known to humankind from times immemorial [1,2]. There are several observations documented in the literature regarding the beneficial effects of the compounds present in these two food gradients [3-5]. Now it is the high time for translating ingredients from kitchen to clinic because of translational and nutrigenomics research. In that context, broccoli and turmeric are two ideal foodstuffs. There are phytochemicals and antioxidant compounds in these two herbs that have profound health benefit ranging from preventive to the curative phase of diseases [6-8]. Antioxidants are believed to be beneficial, but it can act both as friend or foe varying upon the microenvironment of the milieu interior in the scenario of the molecular pathogenesis of a disease $[9,10]$. Clinical Trials with antioxidants have yet not produced many encouraging results $[11,12]$. Instead, other than ascorbic acid (vitamin C) the antioxidants including Vitamin E are proved to increase mortality in all causes $[13,14]$. Therefore, use of antioxidants must consider seriously, and from the point of the molecular pathogenesis of the diseases, their use should be justified. It is found that oxidative stress is associated with most of the diseases [15]. The major noncommunicable chronic diseases of the recent times like diabetes mellitus, obesity, atherosclerosis etc. are related to oxidative stress [16]. In such conditions, supplementations of the antioxidant vitamins are not expected to improve the levels of the antioxidant enzymes [17]. It is particularly noteworthy that the activity of antioxidant enzymes is observed to be diminished in these chronic illnesses. In this context, there is a ray of hope from broccoli and curcumin.

Sulforaphane and curcumin are phytochemicals available abundantly in broccoli and curcumin respectively $[18,19]$. It is seen that both two compounds interact with $\mathrm{Nrf2}$, a transcription factor and causes its translocation in the nucleus from the cytoplasm $[6,8,20]$. In the nucleus, Nrf2 binds with the antioxidant responsive element and induce transcription of detoxification enzymes like glutathione peroxidase, thioredoxin reductase $[21,22]$. This is expected to nullify oxidative stress by stimulating our genetic machinery. Therefore, it is observed that Nrf2 expression plays a beneficial role in inflammation, diabetes mellitus, neurodegenerative disorders etc. [2325]. In malignancy, Nrf2 can have a dual role. Before the initiation of malignancy, it is expected to cause chemoprevention, but in established malignancy, it may inhibit apoptosis of the cancer cells by stimulating the antioxidant machinery of the body [26]. Also, in tuberculosis these phytochemicals can play a negative role as oxidants produced in a respiratory burst may be taken care of by triggering of the oxidant detoxification system and that can make the stay of the intracellular bacilli more comfortable $[27,28]$. The expected molecular interaction of the phytochemicals from broccoli and curcumin is elaborated in Figure 1. We feel that now it is time for focused clinical trial with individual phytochemicals that are observed to be beneficial.

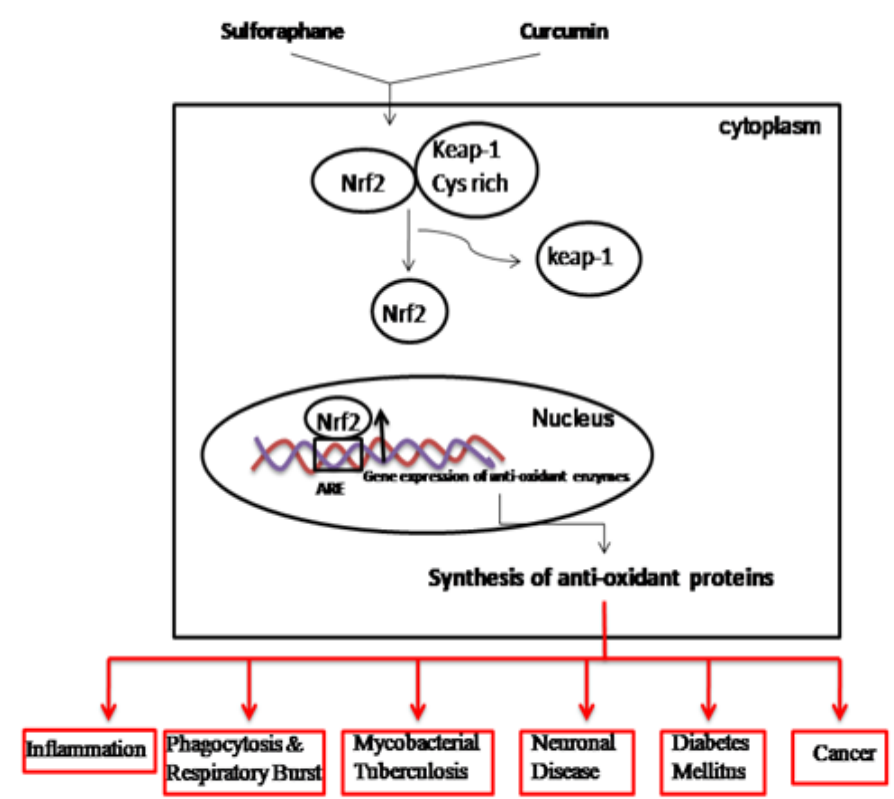

Figure 1. Effect of Sulforaphane and curcumin on anti-oxidant proteins: the effect of Sulforaphane and curcumin in the cells results in the dissociation of Nrf2-Keap-1 complex which releases the keap-1 and then Nrf2 translocates into the nucleus, binds to the antioxidant response element (ARE) sequence and initiates the transcription of gene responsible for synthesis of anti-oxidant enzymes which then moves into the cytoplasm and translate to anti-oxidant proteins and the expression of these protein is expected to affect the molecular pathogenesis of diseases $[8,20]$. In diabetes mellitus and inflammatory disorders action of $\mathrm{N} 2 \mathrm{rf}$ is expected to be beneficial $[23,24]$. While in tuberculosis N2rf may play a negative role [27]. In cancers and neurodegenerative disorders, it may act as a double edged sword $[25,26]$. Focused Clinical trial is necessary to dissect this problem in more detail.

\section{References}

1. Prasad S, Aggarwal BB (2011) Turmeric, the golden spice: from traditional medicine to modern medicine. In: Benzie IFF, Wachtel-Galor S, (eds.) Herbal medicine: biomolecular and clinical aspects. 2nd edition. Boca Raton (FL): CRC Press/Taylor \& Francis.Chapter 13. Available at https://www.ncbi.nlm.nih.gov/books/NBK92752/

2. Buck PA (1956) Origin and taxonomy of broccoli. Economic Botany 10: 250-253.

3. Vaughn AR, Branum A, Sivamani RK (2016) Effects of turmeric (curcuma longa) on skin health: asystematic review of the clinical evidence. Phytother Res 30: 1243-1264. [Crossref]

4. Sciberras JN, Galloway SD, Fenech A, Grech G, Farrugia C et al. (2015) The effect of turmeric (Curcumin) supplementation on cytokine and inflammatory marker responses following 2 hours of endurance cycling. J Int Soc Sports Nutr 12: 5. [Crossref]

Correspondence to: Dibyajyoti Banerjee, Department of Experimental Medicine \& Biotechnology, Post Graduate Institute of Medical Education \& Research Sector 12, Chandigarh, India, Tel: +919780134620; Fax: +91172274440; E-mail: dibyajyoti5200@yahoo.co.in

Received: February 28, 2018; Accepted: March 16, 2018; Published: March 21, 2018 
5. Riso P, Martini D, Visioli F, Martinetti A, Porrini M (2009) Effect of broccoli intake on markers related to oxidative stress and cancer risk in healthy smokers and nonsmokers. Nutr Cancer 61: 232-237. [Crossref]

6. Liu Z, Dou W, Zheng Y, Wen Q, Qin M, et al. (2016) Curcumin upregulates Nrf2 nuclear translocation and protects rat hepatic stellate cells against oxidative stress. Mol Med Rep 13: 1717-1724. [Crossref]

7. Sreejayan, Rao MN (1997) Nitric oxide scavenging by curcuminoids. J Pharm Pharmacol 49: 105-107. [Crossref]

8. Houghton CA, Fassett RG, Coombes JS (2016) Sulforaphane and Other Nutrigenomic Nrf2 Activators: Can the Clinician's Expectation Be Matched by the Reality? Oxid Med Cell Longev 2016: 7857186. [Crossref]

9. Banerjee D, Kaul D (2010) Combined inhalational and oral supplementation of ascorbic acid may prevent influenza pandemic emergency: a hypothesis. Nutrition 26: 128-132.

10. Bhattacharyya R, Banerjee D (2013) Antioxidants: Friend or foe for tuberculosis patients. Adv Biosci Biotechnol 4: 10-14.

11. Goodman M, Bostick RM, Kucuk O, Jones DP (2011) Clinical trials of antioxidants as cancer prevention agents: past, present, and future. Free Radic Biol Med 51: 10681084. [Crossref]

12. Kryscio RJ, Abner EL, Caban-Holt A, Lovell M, Goodman P, et al. (2017) Association of Antioxidant Supplement Use and Dementia in the Prevention of Alzheimer's Disease by Vitamin E and Selenium Trial (PREADViSE). JAMA Neurology 74: 567-573. [Crossref]

13. Abner EL, Schmitt FA, Mendiondo MS, Marcum JL, Kryscio RJ (2011) Vitamin E and all-cause mortality: a meta-analysis. Curr Aging Sci 4: 158-170. [Crossref]

14. Miller ER 3rd, Pastor-Barriuso R, Dalal D, Riemersma RA, Appel LJ, et al. (2005) Meta-analysis: high-dosage vitamin $\mathrm{E}$ supplementation may increase all-cause mortality. Ann Intern Med 142: 37-46. [Crossref]

15. Pham-Huy LA, He H, Pham-Huy C (2008) Free Radicals, Antioxidants in Disease and Health. Int J Biomed Sci 4: 89-96.
16. Ullah A, Khan A, Khan I (2016) Diabetes mellitus and oxidative stress-a concise review. Saudi Pharm J 24: 547-553. [Crossref]

17. Valdés-Ramos R, Ana Laura GL, Elina MCB, Donají BAA (2015) Vitamins and Type 2 Diabetes Mellitus. Endocr Metab Immune Disord Drug Targets 15: 54-63. [Crossref]

18. http://www.phytochemicals.info/phytochemicals/curcumin.php, Accessed 28-02-1018

19. http://www.phytochemicals.info/plants/broccoli.php, Accessed 28-02-2018.

20. Kensler TW, Egner PA, Agyeman AS, Visvanathan K, Groopman JD, et al. (2013) Keap1-nrf2 signaling: a target for cancer prevention by sulforaphane. Top Curr Chem 329: 163-177. [Crossref]

21. Reddy SP (2008) The Antioxidant Response Element and Oxidative Stress Modifiers in Airway Diseases. Curr Mol Med 8: 376-383.

22. Hintz KJ, Wald K, Finley JW (2005) Phytochemicals in broccoli transcriptionally induce thioredoxin reductase. J Agric Food Chem 53: 5535-5540. [Crossref]

23. Ahmed SM, Luo L, Namani A, Wang XJ, Tang X (2017) Nrf2 signaling pathway: Pivotal roles in inflammation. Biochimia et Biophysica Acta 1863: 585-597.

24. Uruno A, Yagishita Y, Yamamoto M (2015) The Keap1-Nrf2 system and diabetes mellitus. Arch Biochem Biophys 566: 76-84. [Crossref]

25. Ramsey CP, Glass CA, Montgomery MB, Lindl KA, Ritson GP, et al. (2007) Expression of Nrf2 in neurodegenerative diseases. J Neuropathol Exp Neurol 66: 75-85. [Crossref]

26. Menegon S, Columbano A, Giordano S (2016) The Dual Roles of NRF2 in Cancer. Trends Mol Med 22: 578-593. [Crossref]

27. Mizuno S, Yamamoto M, Sugawara I (2010) Significant reduction of granulomas in Nrf2-deficient mice infected with Mycobacterium tuberculosis. Indian J Tuberc 57: 108-113. [Crossref]

28. Kovac S, Angelova PR, Holmström KM, Zhang Y, Dinkova-Kostova AT, et al. (2015) Nrf2 regulates ROS production by mitochondria and NADPH oxidase. Biochimica et Biophysica Acta 1850: 794-801.

Copyright: (C2018 Bhattacharyya R. This is an open-access article distributed under the terms of the Creative Commons Attribution License, which permits unrestricted use, distribution, and reproduction in any medium, provided the original author and source are credited. 